\title{
PEMBERDAYAAN MASYARAKAT MELALUI PROGRAM PENDAMPINGAN DESA WISATA DI DESA BEJIJONG KABUPATEN MOJOKERTO
}

\section{COMMUNITY EMPOWERMENT THROUGH VILLAGE TOURISM ASSISTANCE PROGRAMS IN BEJIJONG MOJOKERTO}

\author{
M. NilzamAly ${ }^{1}$, Bambang Suharto ${ }^{1}$, Sri Endah Nurhidayati ${ }^{1}$, Nuruddin ${ }^{1}$, Ria \\ Triwastuti $^{1}$ \\ ${ }^{1}$ Program Studi D3 Kepariwisataan/Bina Wisata, Universitas Airlangga, Jalan \\ Dharmawangsa Dalam No. 28-30, Surabaya, Indonesia, 60286 \\ email: nilzamsvarna@gmail.com
}

\begin{abstract}
Ideally, community empowerment programs in rural areas should not be implemented once in a while. This is very important to maintain the aspect of sustainability and achieve the goals maximally. People in rural areas are the target of empowerment programs considering the many problems that exist there. Statistical data shows that the distribution of the majority of the national poor is in rural areas. One method of reducing poverty is through the development of tourist villages. The purpose of this community service program is to increase the understanding and skills of the community in Bejijong Tourism Village, especially in the field of homestay management and online marketing of citizen handicraft products. The stages in this empowerment program through three methods, namely preparation, implementation, and evaluation. The preparation method was carried out with focus group discussions with residents and field observations. The method of implementation is carried out by the methods of socialization, training and mentoring. Meanwhile, the evaluation method is carried out through discussions with partners. The results of this activity indicate that the understanding and competence of citizens has increased for the better. The results of this activity were measured using a questionnaire (pre-test and post-test) and calculated using a Likert scale.
\end{abstract}

Keywords: Community Empowerment, Sustainablity, Tourism Village, Homestay, Online Marketing

\section{abstrak}

Program pemberdayaan masyarakat di wilayah pedesaan idealnya dilaksanakan tidak dengan sekali waktu. Hal ini menjadi sangat penting untuk menjaga aspek keberlanjutan dan mencapai tujuan secara maksimal. Masyarakat di perdesaan menjadi sasaran program pemberdayaan mengingat banyak sekali permasalahan yang ada di sana. Data statistik menunjukkan sebaran penduduk miskin nasional mayoritas berada di wilayah perdesaan. Salah satu metode untuk mengurangi angka kemiskinan adalah melalui pengembangan desa wisata. Tujuan dari program pengabdian masyarakat ini adalah untuk meningkatkan pemahaman dan keterampilan masyarakat di Desa Wisata Bejijong khususnya dalam bidang pengelolaan homestay dan pemasaran daring produk kerajinan warga. Tahapan dalam program pemberdayaan ini melalui tiga metode yaitu persiapan, pelaksanaan, dan evaluasi. Metode persiapan dilakukan dengan metode focus group discussion bersama warga dan observasi lapangan. Metode pelaksanaan dilakukan dengan metode sosialisasi, pelatihan, dan pendampingan. Sedangkan metode evaluasi dilaksanakan dengan metode diskusi dengan mitra. Hasil kegiatan ini menunjukkan bahwa pemahaman dan kompetensi warga mengalami peningkatan kea rah yang lebih baik. Hasil kegiatan ini diukur dilakukan dengan menggunakan kuesioner (pre tes dan pos tes) dan dihitung dengan skala likert.

Kata kunci: Pemberdayaan Masyarakat, Keberlanjutan, Desa Wisata, Homestay, Pemasaran Daring 


\section{PENDAHULUAN}

Pada periode terakhir, keterlibatan masyarakat pedesaan dalam pembuatan kebijakan lokal telah mendapatkan perhatian yang semakin meningkat sebagai pendekatan alternatif untuk pembangunan pariwisata di Indonesia. Arah pembangunan wilayah pedesaan melalui pariwisata semakin jelas ketika dikeluarkan UU No. 6 Tahun 2014 tentang Desa (Aly et al. 2019).Undang-Undang ini memberikan ruang lebih kepada desa dalam penyelenggaraan sistem pemerintahan terendah yang mempunyai hak dan kewajiban untuk mengatur dan mengurus urusan pemerintahan dan kepentingan masyarakat setempat (Ma'ruf, Kurniawan, and Pangestu 2017). Implementasi atas regulasi ini menjadi sangat penting demi mengurangi angka kemiskinan yang mayoritas masih berada di wilayah perdesaan (Aly and Ruyawari 2019). Fakta tersebut bisa dilihat pada tabel di bawah ini.

Tabel 1. Sebaran Penduduk Miskin di Perdesaan dan Perkotaan

\begin{tabular}{|c|c|c|c|c|c|c|c|}
\hline \multirow{2}{*}{ Wilayah Kemiskinan } & \multicolumn{7}{|c|}{ Tahun } \\
\hline & 2012 & 2013 & 2014 & 2015 & 2016 & 2017 & 2018 \\
\hline $\begin{array}{l}\text { Kemiskinan Perdesaan }(\% \\
\text { penduduk yang hidup di bawah } \\
\text { garis kemiskinan) }\end{array}$ & 8.78 & 8.39 & 8,39 & 14.21 & 14.11 & 13.93 & 13.20 \\
\hline $\begin{array}{l}\text { Kemiskinan Perkotaan }(\% \\
\text { penduduk yang hidup di bawah } \\
\text { garis kemiskinan) }\end{array}$ & 15.12 & 14.32 & 14.17 & 8.29 & 10.34 & 7.72 & 7.02 \\
\hline
\end{tabular}

Sumber: (Badan Pusat Statistik 2018)

Data tersebut memperlihatkan kondisi kesejahteraan yang tidak merata antara wilayah perdesaan dan perkotaan. Kementrian pariwisata dan ekonomi kreatif pada tahun 2013 menyatakan bahwa salah satu solusi alternatif untuk dapat meningkatkan kesejahteraan masyarakat desa khusunya bidang perekonomian adalah dengan mengembangkan sektor pariwisata pedesaan yang berbasis pemanfaatan potensi lokal, baik itu potensi alam maupun keanekaragaman budayanya. Solusi pariwisata tersebut diambil dengan asumsi bahwa pengembangan potensi pariwisata pada gilirannya akan bermuara pada peningkatan kesejahteraan masyarakat (Risman, Wibhawa, and Fedryansyah 2016).

Pendapat yang lebih lama menyatakan bahwa pembangunan pariwisata dan pertumbuhan ekonomi mempunyai hubungan mutualisme untuk mengentaskan kemiskinan (Ashley, Roe, and Goodwin 2001). Lebih jauh lagi, Ashley et al (2001) menyampaikan bahwa pariwisata menjadi media yang cukup efektif untuk menurunkan kemiskinan. Hal ini yang berpengaruh signifikan terhadap terbukanya kesempatan kerja baru, peningkatan pendapatan, kesejahteraan masyarakat, bertumbuhnya pelaku kegiatan ekonomi mikro, dan berkurangnya jumlah penduduk miskin (Darmawan and Yunanto 2016). Berdasarkan dengan penjelasan tersebut maka, pengembangan dan pendampingan desa wisata dianggap sebagai salah satu bentuk pengembangan masyarakat (community development) yang menempatkan masyarakat sebagai aktor utama dalam pengembangan desa wisata tersebut (Risman, Wibhawa, and Fedryansyah 2016).

Pengembangan masyarakat di desa wisata menekankan pada program pemberdayaan masyarakat lokal yang dilakukan secara kolektif dari kelompok-kelompok yang 
terorganisasi untuk mengontrol keputusan, proyek, program, dan kebijakan yang mempengaruhi mereka sebagai sebuah entitas masyarakat. Model pemberdayaan melalui program pendampingan desa wisata dapat menjadi solusi alternatif untuk meningkatkan taraf hidup masyarakat (Halimah, Krisnani, and Fedryansyah 2010). Program pendampingan ini dilaksanakan di Desa Wisata Bejijong Kecamatan Trowulan, Kabupaten Mojokerto. Tujuan program pendampingan desa wisata ini adalah untuk mengajak masyarakat di Desa Wisata Bejijong untuk meningkatkan pemahaman dan keterampilan mereka dalam mengelola potensi wisata yang ada di wilayah mereka.

Desa Bejijong sebagai wilayah yang berstatus sebagai desa wisata telah menerima kunjungan wisatawan baik domestik maupun mancanegara. Selain terdapat beberapa atraksi wisata di Desa Bejijong, warga juga memiliki beberapa usaha jasa yang mendukung aktifitas pariwisata. Usaha jasa warga tersebut adalah produk kerajinan patung kuningan dan homestay. Berdasarkan data hasil observasi lapangan menunjukkan bahwa jumlah homestay yang ada di Desa Bejijong sebanyak 100 buah dan yang aktif difungsikan hanya 32 homestay. Permasalahan yang dihadapi pengelola homestay adalah kesulitan mereka mengelola dan memberikan pelayanan kepada tamu atau wisatawan.

Kondisi serupa juga dihadapi oleh para pengrajin di Desa Bejijong yang berjumlah 400an orang. Mayoritas, para pengrajin tidak memiliki pasar sendiri dalam menjual produk kerajinannya. Sehingga para pengrajin harus menjual produknya ke supplier yang ada di Bali dengan harga yang jauh lebih rendah. Berdasarkan permasalahan tersebut maka program pengabdian masyarakat di Desa Bejijong ini diselenggarakan dengan memberikan pelatihan pengelolaan homestay dan pelayanan prima serta pelatihan pemasran daring bagi para pengrajin kuningan di Desa Bejijong.

\section{METODE PENGABDIAN MASYARAKAT}

Desa Bejijong terletak di Kecamatan Trowulan Kabupaten Mojokerto. Beberapa atraksi wisata yang ada di Desa Bejijong diantaranya adalah Candi Brahu, Patung Budha Tidur, Siti Inggil. Selain itu juga terdapat deretan homestay dengan model arsitektur majapahit serta kerajinan logam yang ditekuni oleh warga di sana. Desa Bejijong memiliki luas wilayah sebesar $\pm 195,185$ Ha dengan penggunaan lahan 127 Ha sebagai tanah sawah dan 68,185 Ha sebagai tanah darat. Desa Bejijong memiliki 2 dusun yaitu: Dusun Bejijong ( $\pm 116.848 \mathrm{Ha})$ dan Dusun Kedungwulan $( \pm 78.337 \mathrm{Ha})$.

Proses pelaksanaan dalam pengabdian masyarakat memiliki beberapa pendekatan. Hal ini bergantung pada fokus masalah yang akan diselesaikan (Nofiyanti, Sulartiningrum, and Fitriana 2018; Oka, Winia, and Pugra 2017). Proses pelaksanaan pendampingan desa wisata Bejijong dilaksanakan melalui tiga tahapan utama, yaitu persiapan, pelaksanaan, dan evaluasi. Masing-masing tahapan akan dijelaskan pada paragraph di bawah ini.

\section{Persiapan}

Tahap persiapan yang dilakukan oleh tim adalah melakukan koordinasi dengan mitra dan melaksanakan observasi lapangan di Desa Bejijong. Selain dari tim dosen, tahapan ini juga melibatkan sebagian mahasiswa dari Program Studi D3 Kepariwisataan/Bina 
Wisata Fakultas Vokasi Universitas Airlangga angkatan 2018. Berikut hasil dokumentasi saat observasi lapangan dan koordinasi dengan mitra yang dilaksanakan pada 30 Maret 2019.
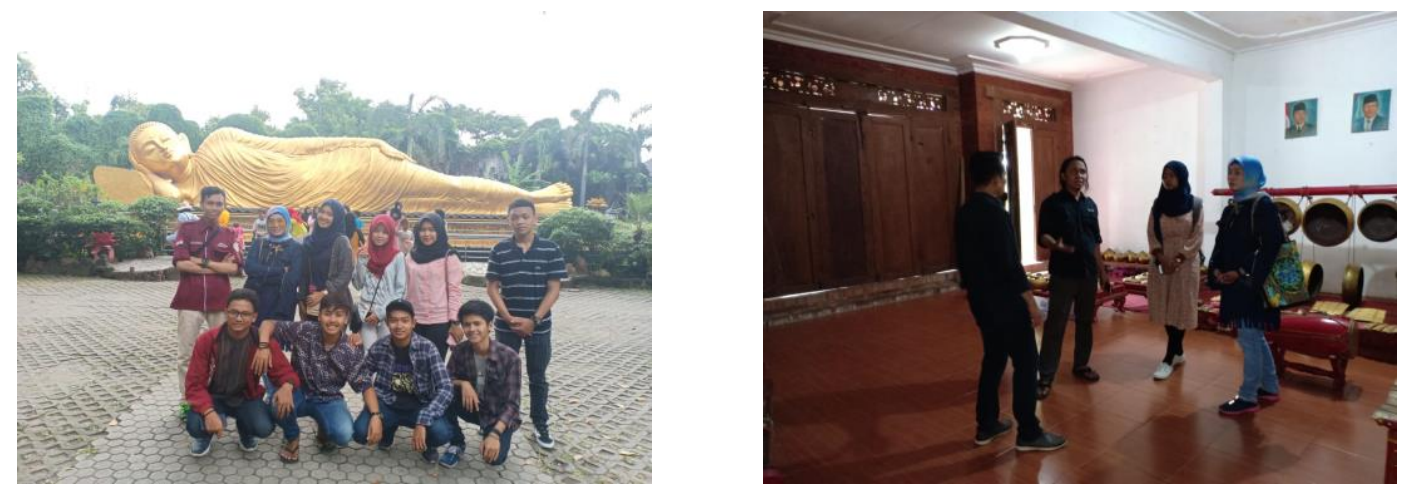

Gambar 1. Kegiatan survei dan Koordinasi dengan Mitra

Mitra yang dimaksud dalam kegiatan pendampingan adalah Bapak Supriyadi selaku tokoh masyarakat dalam pengelolaan Desa Wisata Bejijong sekaligus pemilik Sanggar Bagaskara. Seluruh koordinasi dilakukan secara penuh antara Tim Pendamping dengan Bapak Supriyadi.

\section{Pelaksanaan}

Tahap pelaksanaan terbagi dalam tiga kegiatan, yaitu:

a. Sosialisasi

Hasil koordinasi dengan mitra menyimpulkan bahwa pelaksanaan sosialisasi dengan warga dilaksanakan pada 27-28 April 2019. Selain dari tim dosen, pada tahap ini juga melibatkan seluruh mahasiswa dari Program Studi D3 Kepariwisataan/Bina Wisata Fakultas Vokasi Universitas Airlangga angkatan 2018. Tugas mahasiswa adalah melakukan wawancara dan mengobservasi kondisi lapangan yang dibagi dalam 6 bidang; Atraksi, Homestay, Flora Fauna, SPA, Kuliner, dan Kerajinan.

Tujuan keterlibatan mahasiswa dalam proses analisis kondisi lapangan diantaranya adalah untuk:

1. Mendengarkan permasalahan, dan pemikiran dari warga;

2. Menyesuaikan diri dengan masyarakat;

3. Berkomunikasi secara efektif untuk menggali informasi dari warga;

4. Mengidentifikasi potensi warga dan wilayahnya

Pada tanggal 27 April malam, mahasiswa melakukan presentasi dari hasil wawancara dan analisis kondisi lapangan di depan warga dan dosen pendamping. Setelah itu dilanjutkan dengan sosialisasi tentang program pendampingan yang akan dilakukan oleh tim dari Universitas Airlangga dan Kementerian Pariwisata. Selain itu, malam itu juga disampaikan tentang peran strategis desa wisata dalam meningkatkan kompetensi dan kesejahteraan masyarakat. 


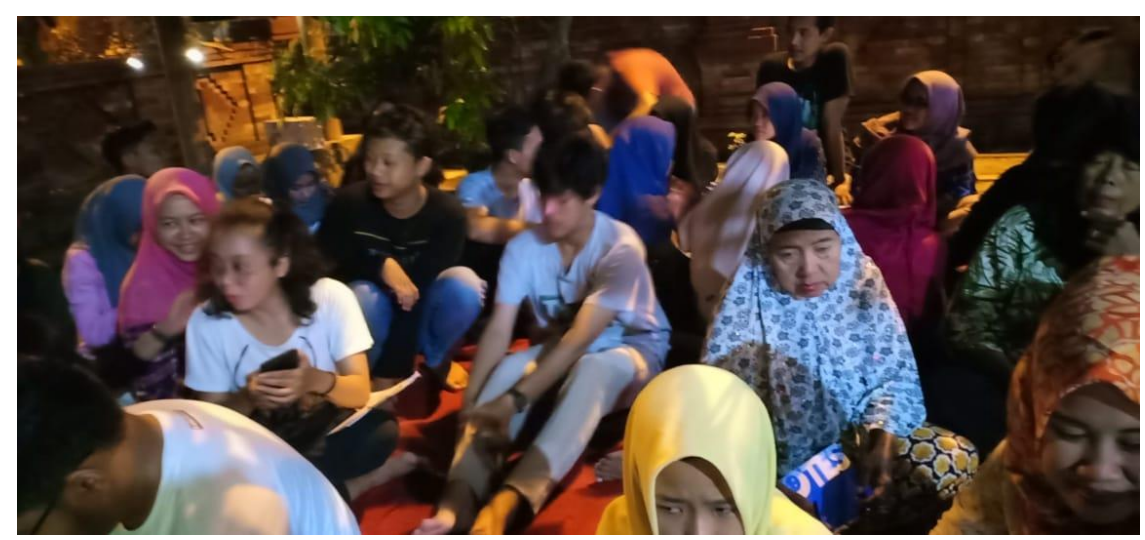

Gambar 2. Presentasi Mahasiswa tentang Hasil Analisis Kondisi Lapangan

\section{b. Pelatihan}

Pada tanggal 28 April dilaksanakan kegiatan pelatihan yang pertama mengenai pengelolaan homestay, dan pelayanan prima (service excellent) yang meliputi making bed, penyajian kuliner, dan penataan ruang homestay. Kegiatan pelatihan ini dilaksanakan di Homestay Ken Dedes milik warga dengan mengoptimalkan sumber daya lokal sebagai medianya.

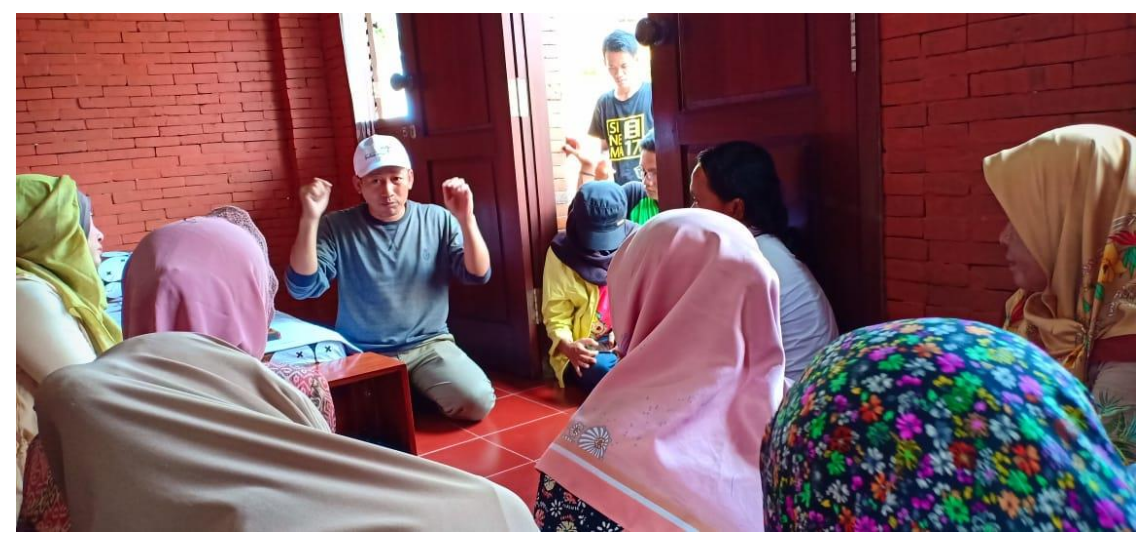

Gambar 3. Kegiatan Pelatihan 1

Kegiatan pelatihan yang kedua dilaksanakan pada 25 Mei 2019 dengan materi tambahannya adalah pelatihan pemasaran daring (online) produk kerajinan tangan bagi para pengrajin di Desa Bejijong.

\section{c. Pendampingan}

Pada hari yang sama, Sabtu 25 Mei 2019, tim dosen juga melakukan pendampingan dari hasil sosialisasi dan pelatihan pada tanggal 27-28 April 2019. Proses pendampingan ini dilakukan untuk melihat hasil pelatihan yang telah dilakukan sebagai bagian dari prinsip keberlanjutan dan kemandirian warga. Kegiatan pendampingan dilakukan dengan memberikan pertanyaan (pre-test dan post-test) yang hasilnya akan disampaikan lebih detail pada bagian analisis. 


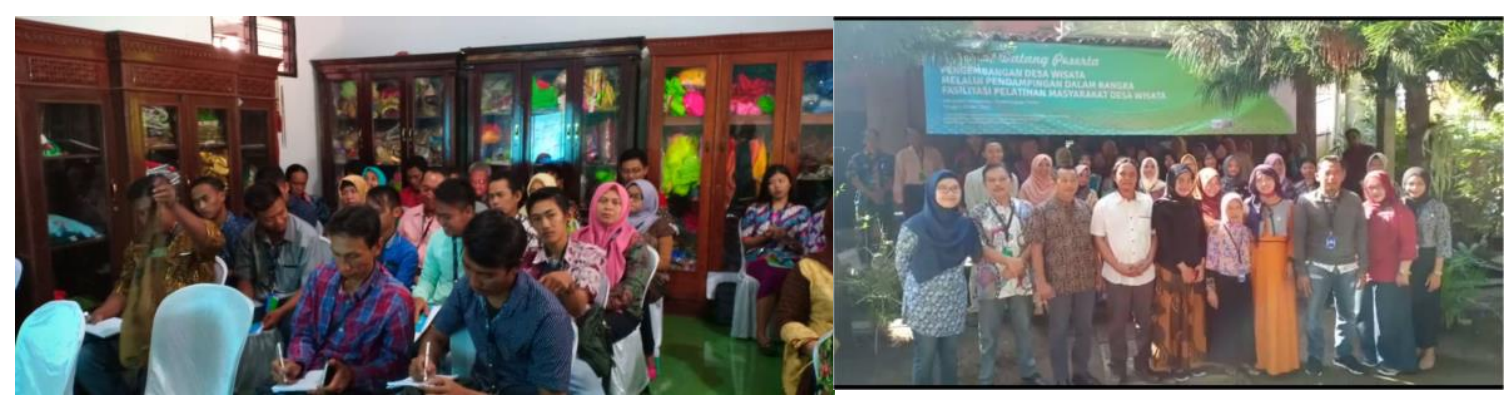

Gambar 4. Peserta Pelatihan 2 dan Pemateri pada tanggal 25 Mei 2019

\section{Evaluasi}

Tahap evaluasi dilakukan dengan melakukan diskusi dengan mitra yang diwakili oleh Bpk. Supriadi selaku tokoh masyarakat yang terlibat langsung dalam serangkaian program pendampingan desa wisata. Evaluasi dilakukan pada tanggal 25 Mei 2019 setelah acara pelatihan 2 .

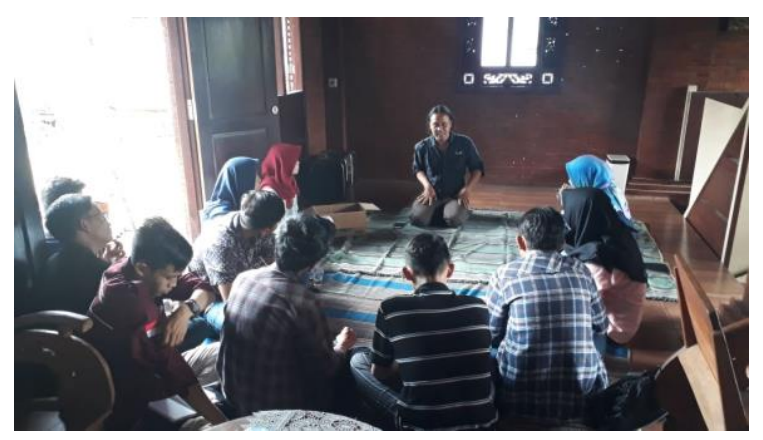

Gambar 5. Kegiatan evaluasi melalui diskusi

\section{HASIL DAN PEMBAHASAN}

Kuantitas demografis peserta pelatihan sebanyak 49 peserta dengan sebaran sebanyak 14 peserta adalah laki-laki dan 35 peserta berjenis kelamin perempuan. Peserta yang hadir merupakan hasil penunjukan yang dilakukan oleh mitra dengan dasar merupakan pelaku industri aktif di bidang pariwisata (pengelola homestay, kerajinan tangan, pokdarwis, perangkat desa).

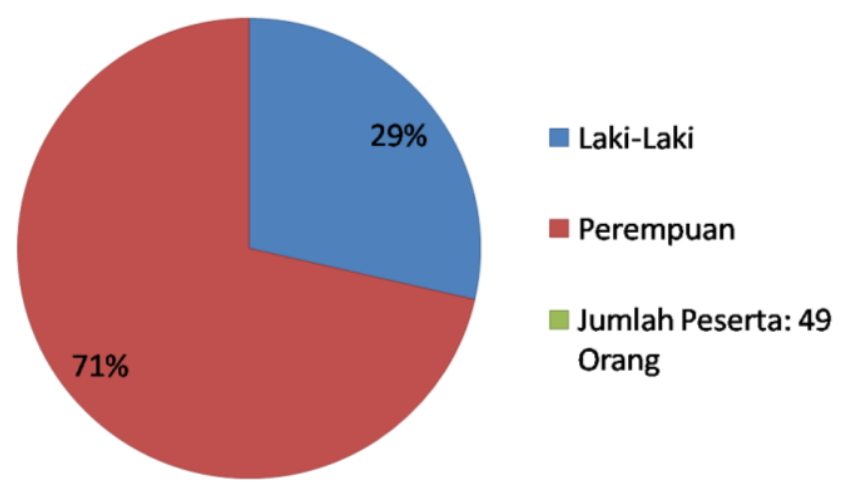

Gambar 6. Diagram Jumlah Peserta Program Pelatihan 
Data di atas menunjukkan bahwa peserta dengan jenis kelamin perempuan jauh lebih banyak (71\%) dibandingkan dengan jumlah peserta berjenis kelamin laki-laki (29\%). Peserta perempuan lebih dominan karena mayoritas dari mereka adalah kelompok pengelola homestay (30 orang) yang ada di Desa Bejijong. Berdasarkan kelompok usia, peserta paling muda berusia 18 tahun dan paling tua berusia 71 tahun semuanya berjenis kelamin perempuan. Mayoritas peserta pria memiliki latar belakang aktfitas di kelompok sadar wisata (7 orang) dan pengrajin patung kuningan (4 orang). Selebihnya berlatar belakang sebagai aparat desa (2 orang) dan guru (1 orang).

\section{Hasil Analisis Pre-Test dan Post-Test}

Secara keseluruhan, rangkaian kegiatan pendampingan mendapat respon positif dari peserta dan warga Desa Bejijong. Hasil pre-test dan post-tes menunjukkan hasil yang sangat positif bahwa pengetahuan dan keterampilan warga tentang SE (Service Excellent), OM (Online Marketing), dan SW (Sadar Wisata) meningkat lebih baik. Data yang digunakan bersumber dari kuesioner yang diisi oleh 49 responden $(n=49)$.

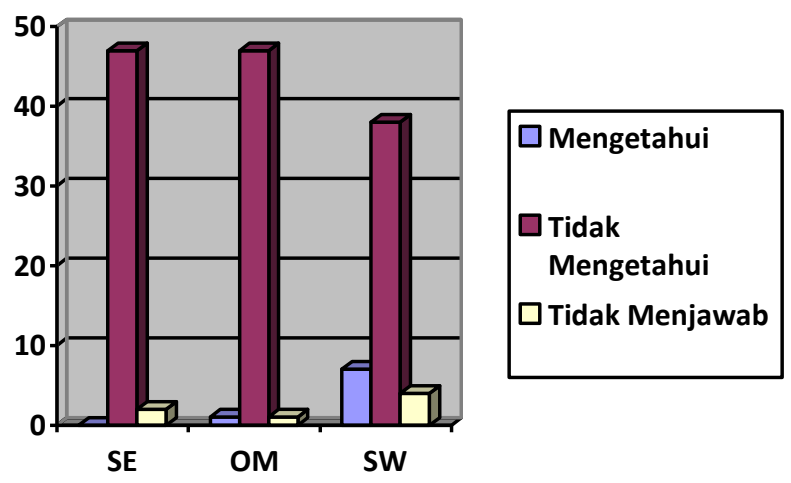

Gambar 7. Hasil Pre Test: Pengetahuan Masyarakat tentang SE (Service Excellent); OM (Online Marketing); SW (Sadar Wisata)

Data pre-test menunjukkan bahwa mayoritas peserta belum mengetahui tentang materi pelayanan prima, pemasaran daring, dan sadar wisata. Sehingga materi yang disampaikan saat pelatihan dan pendampingan berbicara mengenai ini semua. Materi yang disampaikan merupakan hasil diskusi antara pemateri dengan pengelola desa wisata dan pemerintah Desa Bejijong. 

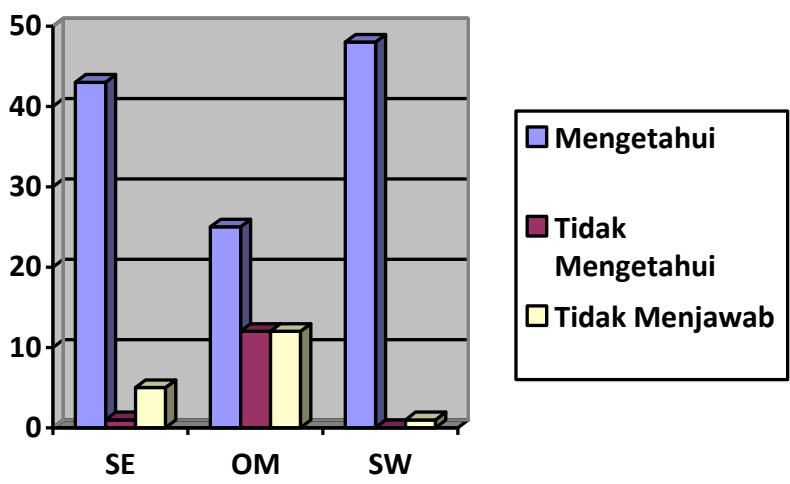

Gambar 8. Hasil Post Test: Pengetahuan Masyarakat tentang SE (Service Excellent); OM (Online Marketing); SW (Sadar Wisata)

Proses evaluasi kinerja pelaksanaan program pendampingan desa Wisata dalam upaya meningkatkan kualitas desa wisata, maka diperlukan pendekatan terlebih dahulu terhadap hubungan antara input, output, outcome, serta impact dari program kegiatan tersebut. secara jelasnya dapat dilihat pada gambar berikut:

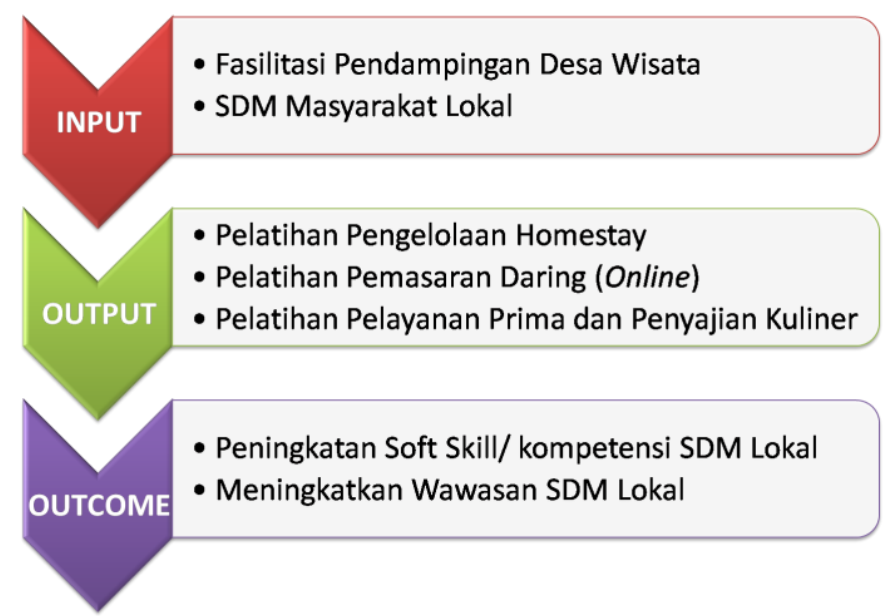

Gambar 9. Analisis Input-Output-Outcame Pasca Pendampingan

Pasca kegiatan pendampingan hasil evaluasi menunjukkan bahwa hubungan yang terwujud baru antara Input-Output-Outcame belum sampai pada hubungan impact. Oleh karena itu hasil evaluasi menunjukkan bahwa perlu ada kegiatan pendampingan lanjutan untuk menambah hasil outcame dan mendatangkan impact positif seperti yang terlihat pada gambar berikut ini. Berdasarkan Gambar 8 dapat dilihat bahwasanya input dari kegiatan pendampingan berupa komponen fisik, dimana input tersebut mencerminkan sumberdaya yang nantinya akan menghasilkan output. Input tersebut yaitu berupa fasilitasi dari Kementrian Pariwisata dan Perguruan Tinggi, yang meliputi bantuan dalam bentuk konsultasi manajemen, tim teknis, serta penyediaan tim fasilitator yang akan mendampingi dalam tahapan perencanaan serta penyelenggaraan program kegiatan pendampingan desa wisata lanjutan. 
Kemudian, untuk output yang tercipta dari kegiatan pendampingan adalah kebutuhan yang meliputi pemenuhan sarana pendukung untuk kegiatan pariwisata di desa wisata. Sarana tersebut berupa sarana non-fisik berupa pelatihan pengelolaan homestay, pelatihan pemasaran daring, dan pelatihan pelayanan prima. Kemudian outcome dari kegiatan pendampingan desa wisata ini adalah peningkatan soft skill dan wawasan masyarakat Desa Bejijong. Pencapaian outcome mencerminkan manfaat jangka menengah yang merupakan hasil dari bekerjanya aspek output dari kegiatan pendampingan desa wisata. Hubungan antar proses ini telah terwujud selama proses pendampingan sampai evaluasi.

Gambar 9 merupakan hasil evaluasi yang menyimpulkan bahwa perlu diadakan program lanjutan yang berfokus pada pemasaran daring khususnya pembuatan akun di platform penjualan produk kerajinan internasional seperti etsy.com dan artsy.net. Selain itu juga perlu pelatihan dan pembuatan akun paypal untuk transaksi bisnis internasional. Kondisi ini untuk menambah kualitas outcome dan memberikan dampak (impact) signifikan dari program pendampingan lanjutan. Selain pemasaran daring hasil evaluasi juga menunjukkan bahwa program peningkatan kemampuan kebahasaan (Indonesia dan Inggris) untuk pemuda yang tergabung dalam kelompok sadar wisata perlu diwujudkan serta elompok Ibu-ibu pengelola homestay perlu diberikan pelatihan lanjutan untuk mampu membuat kemasan yang lebih layak jual dan diversifikasi produk kuliner. Keterlibatan masyarakat dalam kegiatan usaha pariwisata di Desa Wisata Bejijong dapat dilihat dari keterlibatan individu serta keterlibatan dari anggota keluarga. Hasil analisis terhadap keterlibatan individu menunjukkan hampir $100 \%$ responden menyatakan terlibat dalam pengembangan Desa Wisata Bejijong.

\section{PENUTUP}

\section{SIMPULAN}

Program pendampingan desa wisata ini memiliki dampak positif terhadap pemahaman dan keterampilan warga dalam pengembangan usaha pariwisata. Mitra memiliki harapan besar agar diselenggarakan program pendampingan lanjutan dengan tema sejenis (pemasaran daring) serta program peningkatan kemampuan kebahasaan (Indonesia dan Inggris) untuk pemuda yang tergabung dalam kelompok sadar wisata (pokdarwis). Kelompok Ibu-ibu pengelola homestay perlu diberikan pelatihan lanjutan untuk mampu membuat kemasan yang lebih layak jual. Selain itu diversifikasi produk kuliner dan oleh-oleh perlu untuk segera dipikirkan bersama agar sektor ekonomi warga juga terangkat dengan adanya pariwisata.

\section{UCAPAN TERIMA KASIH}

Program pendampingan desa wisata di Desa Bejijong merupakan hasil kerjasama yang baik antara Kementerian Pariwisata dan Ekonomi Kreatif dengan Universitas Airlangga melalui Program Studi D3 Kepariwisataan/Bina Wisata. Oleh karena itu secara khusus penulis mengucapkan terimakasih pada kedua institusi tersebut. Tak lupa juga ucapan terimakasih kami sampaikan kepada Mas Supriadi dan keluarga besar Sanggar Bagaskara yang telah menjadi mitra strategis untuk mensukseskan rangkaian program pendampingan desa wisata di Desa Bejijong. 


\section{DAFTAR PUSTAKA}

Aly, M. Nilzam et al. 2019. "Public Policy and Rural Tourism Development in East Java Province, Indonesia." African Journal of Hospitality, Tourism and Leisure 2019(Special Issue): 1-8.

Aly, M. Nilzam, and Marlin Pernilawati Susilawati Ruyawari. 2019. "Utilization Of Waste Corncrbs as Mushroom Cultivication Media in the Pataan Village Lamongan District." Darmabakti Cendekia: Journal of Community Service and Engagements 1(2): 34-38.

Ashley, C., D. Roe, and H Goodwin. 2001. The Russell Press Pro-Poor Tourism Strategies: Making Tourism Work For The Poor (A Review of Experience). Nottingham.

Badan Pusat Statistik. 2018. "Persentase Penduduk Miskin." BPS. https://www.bps.go.id/pressrelease/2018/07/16/1483/persentase-pendudukmiskin-maret-2018-turun-menjadi-9-82-persen.html.

Darmawan, Dody Harris, and Adi Yunanto. 2016. "Peluang Pariwisata Dalam Menurunkan Kemiskinan Di Era Masyarakat Ekonomi Asean (Mea).” Jurnal Riset Ekonomi dan Manajemen 16(2): 199.

Halimah, Mamah, Hetty Krisnani, and Muhammad Fedryansyah. 2010. "Partisipasi Masyarakat Dalam Program Pengelolaan." In Prosiding Penelitian Dan Pengabdian Kepada Masyarakat, , 157-62.

Ma'ruf, Muhammad Farid, Badrudin Kurniawan, and Rizky Purna Aji Galih Pangestu. 2017. "Desa Wisata: Sebuah Upaya Mengembangkan Potensi Desa Dan Meningkatkan Pendapatan Asli Desa (Studi Pada DesaWisata Bejiharjo Kecamatan Karangmojo Kabupaten Gunungkidul)." Dinamika Governance 7(2): 193-203.

Nofiyanti, Fifi, Sri Sulartiningrum, and Rina Fitriana. 2018. "Pelatihan Peningkatan Kualitas SDM Bidang Pariwisata Di Desa Wisata Cikolelet Serang Banten.” Jurnal SOLMA 7(2): 176.

Oka, I Made Darma, I Nyoman Winia, and I Wayan Pugra. 2017. "Pemberdayaan Masyarakat Melalui Pelatihan Pengolahan Masakan Seafoods Untuk Menunjang Pariwisata Di Desa Wisata Serangan.” Bhakti Persada: Jurnal Aplikasi IPTEKS 1(1): 62. http://ojs.pnb.ac.id/index.php/BP/article/view/250.

Risman, Apep, Budhi Wibhawa, and Muhammad Fedryansyah. 2016. "Kontribusi Pariwisata Terhadap Peningkatan Kesejahteraan Masyarakat Indonesia." Prosiding Penelitian dan Pengabdian kepada Masyarakat 3(1): 29-37. 